\title{
Steroid and pituitary hormone concentrations in the fluid of preovulatory bovine follicles relative to the peak of LH in the peripheral blood
}

\author{
S. J. Dieleman, M. M. Bevers, J. Poortman* and H. T. M. van Tol \\ Clinic for Veterinary Obstetrics, A.I. and Reproduction, State University of Utrecht, Yalelaan 7, \\ De Uithof, 3508 TD Utrecht, and *Department of Endocrinology, University Hospital, State \\ University of Utrecht, Catharijnesingel 101, Utrecht, The Netherlands
}

\begin{abstract}
Summary. Preovulatory bovine follices $(n=73)$ were collected at different times after the onset of oestrus until shortly before ovulation, which occurred at $24 \pm 1.4 \mathrm{~h}$ after the peak concentration of $\mathbf{L H}$ in the peripheral blood. Non-atretic antral follicles $(n=$ 9) of 15-19 mm were also collected from cows during the luteal phase of the oestrous cycle. Follicular fluid concentrations of dehydroepiandrosterone, androstenedione and oestrone, and of LH, FSH and prolactin were compared in 2-h periods relative to the LH plasma peak. Before the LH surge the concentrations of the steroids were much higher than in non-atretic luteal-phase follicles of similar size. From 0 to $6 \mathrm{~h}$ after the LH peak the steroid concentrations decreased sharply to remain low until ovulation; only that of androstenedione increased again after $14 \mathrm{~h}$ to remain constant. The ratio between the concentrations of androstenedione and dehydroepiandrosterone remained constant until $14 \mathrm{~h}$ after the LH peak; at $14 \mathrm{~h}$ it increased about 4-fold and remained high until ovulation. The ratio between the oestrone and androstenedione concentration increased gradually to a 10 -fold higher value until at $14 \mathrm{~h}$ an abrupt decrease was observed. These changes indicate that after the LH peak androgen production is directly inhibited and, at a slower rate, the aromatizing activity. Androstenedione appeared to be the major aromatase substrate.

Before the plasma LH peak the follicular fluid concentration of FSH was higher than in luteal-phase follicles; the concentrations of $\mathrm{LH}$ and prolactin were not different from those in luteal-phase follicles. About $4 \mathrm{~h}$ after the LH plasma peak the LH concentration in follicular fluid reached a maximum, which was one seventh of that in peripheral blood; it remained elevated until $20 \mathrm{~h}$. The FSH concentration was higher after the LH plasma peak than before; just before ovulation it was still 2 -fold higher. The concentration of prolactin fluctuated throughout the preovulatory development from the onset of oestrus until ovulation. It is suggested that oestradiol biosynthesis in bovine preovulatory follicles is terminated by an inhibitory action of the preovulatory LH peak on androgen production.
\end{abstract}

\section{Introduction}

In the cow the oestradiol concentration in the fluid of preovulatory follicles decreases about $6 \mathrm{~h}$ after the preovulatory peak of luteinizing hormone (LH) (Dieleman, Kruip, Fontijne, de Jong \& van der Weyden, 1983). It is not clear, however, whether oestradiol biosynthesis is terminated by 
inhibition of aromatizing activity or of androgen production, and which androgen serves as substrate for aromatase. In-vitro studies by Fortune \& Hansel (1979) indicated that the aromatizing capacity of bovine granulosa cells is diminished 10-15 h after the preovulatory LH peak, while Suzuki \& Tamaoki (1980) suggested that in the rat thecal androgen production is inhibited after ovulation, causing depletion of the substrate for oestrogen synthesis. Since in-vitro studies with rat follicles (Wang \& Chan, 1982) showed that follicle-stimulating hormone (FSH) and prolactin act directly on granulosa steroid production, LH may not be the only regulating factor of steroidogenesis in preovulatory follicles. Although several reports describe the concentration of androstenedione and pituitary hormones in ovarian follicular fluid in different mammalian species (e.g. Peters \& McNatty, 1980; McNatty, Gibb, Dobson, Thurley \& Findlay, 1981b; Henderson, McNeilly \& Swanston, 1982), information is scarce about alterations of hormone concentrations in follicular fluid during preovulatory development in normal cyclic animals. We therefore investigated the changes occurring in vivo in the concentrations of dehydroepiandrosterone, androstenedione and oestrone, and of LH, FSH and prolactin in the fluid of preovulatory bovine follicles in relation to the preovulatory peak of LH. For comparative purposes, large non-atretic follicles were also collected during the luteal phase of the oestrous cycle, since this is a period when basal follicular fluid concentrations of pituitary hormones can be expected (Ireland \& Roche, 1983).

\section{Materials and Methods}

\section{Collection of follicles}

The preovulatory follicles from normally cyclic Dutch-Friesian heifers $(n=43)$ and cows $(n=$ 11) were those used previously (Dieleman et al., 1983); the ovaries had been recovered at known intervals after onset of oestrus until ovulation. The collection was expanded with another 19 preovulatory follicles from Dutch-Friesian heifers. The housing of the animals, assessment of the luteal function by estimating the progesterone concentration in the peripheral blood with a rapid radioimmunoassay (RIA) twice a day and detection of oestrus, were as described previously (Dieleman et al., 1983), as were recovery of the ovaries by ovariectomy, dissection of the follicles, processing of the fluid, collection of blood samples and RIA of LH in plasma. For comparative purposes the 9 follicles 15-19 mm in diameter (Dieleman et al., 1983), collected during the luteal phase of the oestrous cycle, were examined for steroids and pituitary hormones in the follicular fluid. Small pieces of the follicular wall were fixed in Bouin's fluid and embedded in paraffin wax; sections of $7 \mu \mathrm{m}$ were stained with haematoxylin-eosin and periodic acid-Schiff's reagents. The follicles used in this study were designated as non-atretic according to the criteria described by Kruip \& Dieleman (1982). There was no difference in size of follicles originating from heifers or cows and the diameter varied from 13.7 to $19 \mathrm{~mm}$ independently of the stage of preovulatory development.

\section{Radioimmunoassay of hormones in follicular fluid}

Steroids. Concentrations of dehydroepiandrosterone, androstenedione and oestrone were estimated by previously validated RIA methods (Dieleman \& Schoenmakers, 1979; Van Landeghem et al., 1981). The mean recoveries $(n=50)$ were $82.3 \pm 5.9$ (s.d.) $\%$ after celite column chromatography, $80.9 \pm 7.3 \%$ after extraction and $78.1 \pm 6.9 \%$ after chromatography on Sephadex LH-20 respectively. The intra- and interassay coefficients of variation were $\leqslant 11$ and $\leqslant 14 \%(n \geqslant 12)$, respectively, and the sensitivity was at least $60 \mathrm{fmol} /$ tube.

Pituitary hormones. Concentrations of FSH, prolactin and LH were estimated in one assay for each hormone by RIA methods similar to those described by Cheng (1978), Bevers, Willemse \& Kruip (1978) and Dieleman et al. (1983), respectively; the intra-assay coefficients of variation were 
all $<7 \%$. Concentrations of $\mathbf{L H}$ were estimated with an homologous double-antibody RIA. The antiserum (8101), final dilution 1:1 000 000, was raised in rabbit against bovine LH (bLH-7981), which was purified according to Closset, Vandalem \& Hennen (1975) and Beckers, Closset, Maghuin-Rogister \& Hennen (1977) of a crude pituitary extract generously supplied by Organon (Oss, The Netherlands), and bLH-7981 was used for iodination and standard curve. Crossreactions were $130 \%$ for bovine $\mathrm{LH}$ NIH-LH-B4, 33\% for bovine LH NIH-LH-B9, $2 \%$ for bovine FSH NIH-FSH-B1, $<0.02 \%$ for bovine prolactin NIH-P-B3 and $<0.5 \%$ for bovine growth hormone NIH-GH-B18. The sensitivity was $0.12 \mu \mathrm{g} / 1$ follicular fluid. For the RIA of FSH, the antiserum and bFSH were generously supplied by Dr K. W. Cheng; the cross-reactions were $0 \cdot 2 \%$ for bLH-7981, and $<0.01 \%$ for NIH-P-B3 and NIH-GH-B18. The sensitivity was $0.70 \mu \mathrm{g} / 1$; concentrations of FSH below the detection limit were arbitrarily assigned a value of $0.35 \mu \mathrm{g} / 1$. For the RIA of prolactin the antiserum was generously supplied by Dr H. G. Kwa of the Netherlands Cancer Institute, and NIH-P-B3 was used for iodination and the standard curve. Cross-reactions were $0.6 \%$ for NIH-GH-B18, and $<0.007 \%$ for bovine LH (LER-1972-2) and NIH-FSH-B1. The sensitivity was $0.32 \mu \mathrm{g} / \mathrm{l}$. LH, FSH and prolactin values are expressed in terms of NIH-LH-B9, bFSH and NIH-P-B3 respectively.

\section{Statistical analysis}

Student's $t$ test (two-tailed) was used to compare the means of two samples. Differences between the means of samples in grouped data were tested for significance by analysis of variance according to Scheffé (1959).

\section{Results}

Steroid and pituitary hormone concentrations in the fluid of preovulatory follicles

The time when the maximum LH concentration was recorded in peripheral blood was defined as the LH peak (time 0 ). The mean \pm s.d. intervals between the onset of oestrus and the onset of the LH surge (first elevated concentration of $\mathrm{LH}$ followed by higher values) and the maximum $\mathrm{LH}$ values were $1.73 \pm 2.35$ and $4.63 \pm 2.67 \mathrm{~h}(n=33)$ respectively. Ovulation occurred $24 \pm 1.4$ (s.d.) $\mathrm{h}(n=4)$ after the LH peak (Dieleman et al., 1983).

Steroids. In preovulatory follicles collected before the LH surge the mean \pm s.e.m. concentrations ( $\mu \mathrm{mol} / 1, n=10)$ of dehydroepiandrosterone, androstenedione and oestrone in the fluid were $0.19 \pm 0.04,1.37 \pm 0.24$ and $0.47 \pm 0.08$ respectively. After the LH peak 44 follicles were collected over $2-\mathrm{h}$ periods, the last period being $22-25 \mathrm{~h}$ after the LH peak. Text-figure 1 presents the mean concentrations and molar ratios for the measured steroids at each period; those of testosterone and oestradiol had been estimated previously (Dieleman et al., 1983). The dehydroepiandrosterone concentration in the fluid of follicles collected before the LH surge was not significantly different from that during $0-2$ and $2-4 \mathrm{~h}$ after the $\mathrm{LH}$ peak. After $4 \mathrm{~h}$, the concentration decreased abruptly $(P<0.001)$ to remain constant until ovulation. The apparent initial decrease of the ratio between the androstenedione and dehydroepiandrosterone concentration was not significant; it remained constant until $14 \mathrm{~h}$ after the $\mathrm{LH}$ peak. The test for covariance between the concentrations of the two steroids in this period showed a correlation coefficient 0.82 $(P<0 \cdot 001)$. The ratio from $14 \mathrm{~h}$ to ovulation was significantly higher $(P<0.001)$ than before $14 \mathrm{~h}$ after the LH peak. The androstenedione concentration before the LH peak (Text-fig. 1) was significantly higher $(P<0.001)$ than that after the LH peak. Between 0 and $8 \mathrm{~h}$ after the LH peak the concentration decreased sharply $(P<0.05)$ and remained low until $14 \mathrm{~h}$. In the next $11 \mathrm{~h}$ until ovulation the concentration was higher $(P<0.05)$ than that between 8 and $14 \mathrm{~h}$ after the LH peak. The pattern of the androstenedione concentration therefore showed three different phases after the LH peak. The ratio between the oestrone and androstenedione concentrations increased after the 


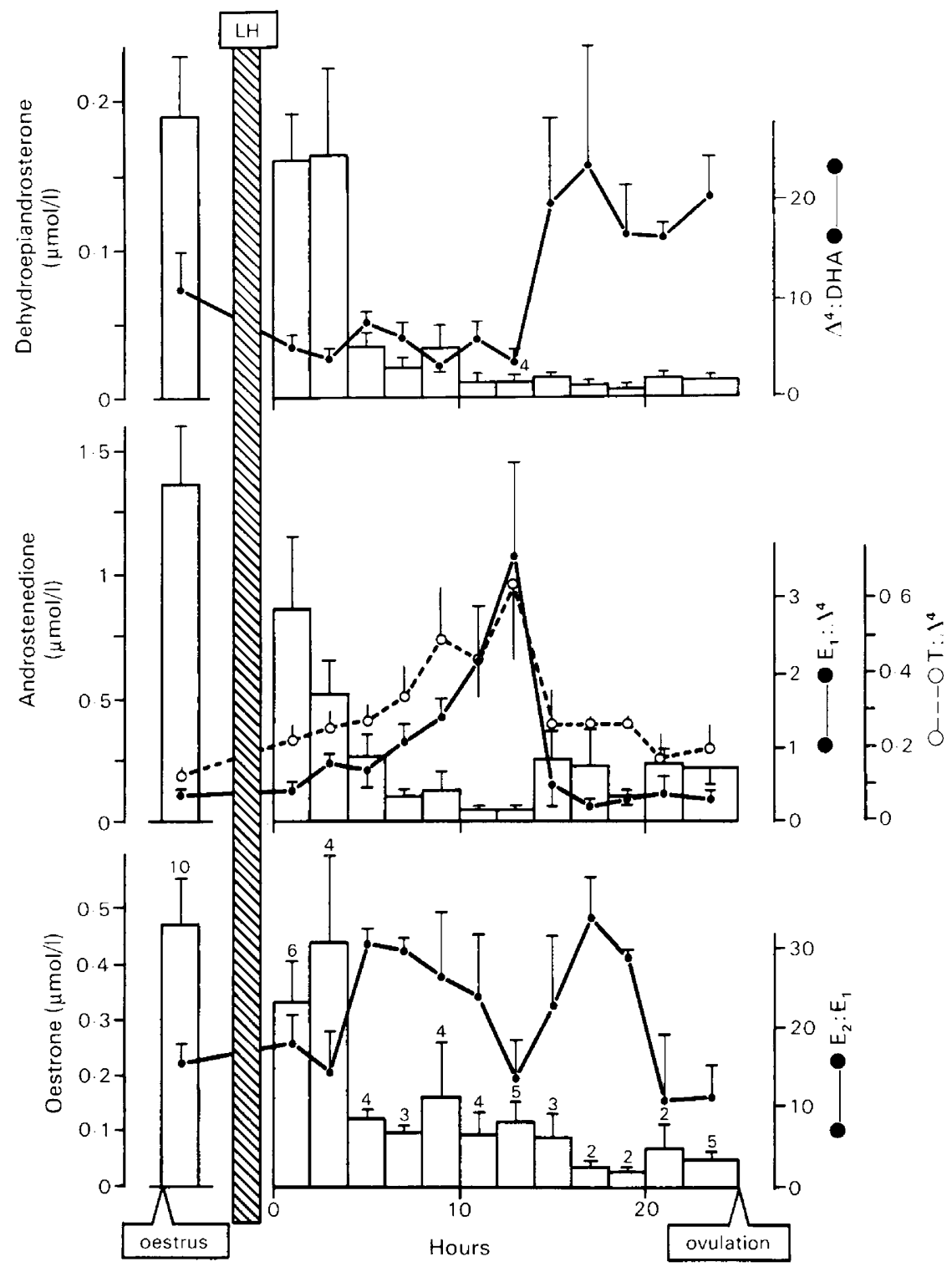

Text-fig. 1. Steroid concentrations in the fluid of preovulatory bovine follicles from the onset of oestrus until ovulation measured in 2-h periods relative to the maximum LH concentration in the peripheral blood. Values are mean \pm s.e.m. for the numbers of follicles indicated.

LH peak until $14 \mathrm{~h}$; the ratio in the period $12-14 \mathrm{~h}$ was significantly higher $(P<0.05)$ than that at $0-2 \mathrm{~h}$ and $22-25 \mathrm{~h}$ after the $\mathrm{LH}$ peak. After $14 \mathrm{~h}$ until ovulation the ratio had returned to that before the $\mathrm{LH}$ peak. The ratio between the testosterone and androstenedione concentration increased after the LH peak until $14 \mathrm{~h}$; the ratio at $12-14 \mathrm{~h}$ was significantly higher $(P<0.001)$ than that before the LH surge. After $14 \mathrm{~h}$ the ratio fell significantly $(P<0.005)$ to a value which remained constant until ovulation; this value was not significantly different from that before the LH surge. The oestrone concentration in the fluid of follicles collected before the LH surge (Text-fig. 1) was not significantly different from that during $0-4 \mathrm{~h}$ after the LH peak; it was, however, significantly 
higher $(P<0.001)$ than the concentration thereafter. From 4 to $14 \mathrm{~h}$ the concentration remained constant; the apparent decrease until $20 \mathrm{~h}$ and the subsequent 2-fold increase of the oestrone concentration were not significant. The ratio between the oestradiol and oestrone concentration in the fluid of follicles collected before the LH surge until $4 \mathrm{~h}$ after the LH peak was significantly lower $(P<0.025)$ than that from 4 to $12 \mathrm{~h}$. After the drop $(P<0.05)$ at $12-14 \mathrm{~h}$ the apparent increase of the ratio until $20 \mathrm{~h}$ after the LH peak was not significant. Just before ovulation the ratio fell $(P<$ 0.05 ) to values similar to those before the $\mathrm{LH}$ peak.

Pituitary hormones. In preovulatory follicles collected before the LH surge the mean \pm s.e.m.
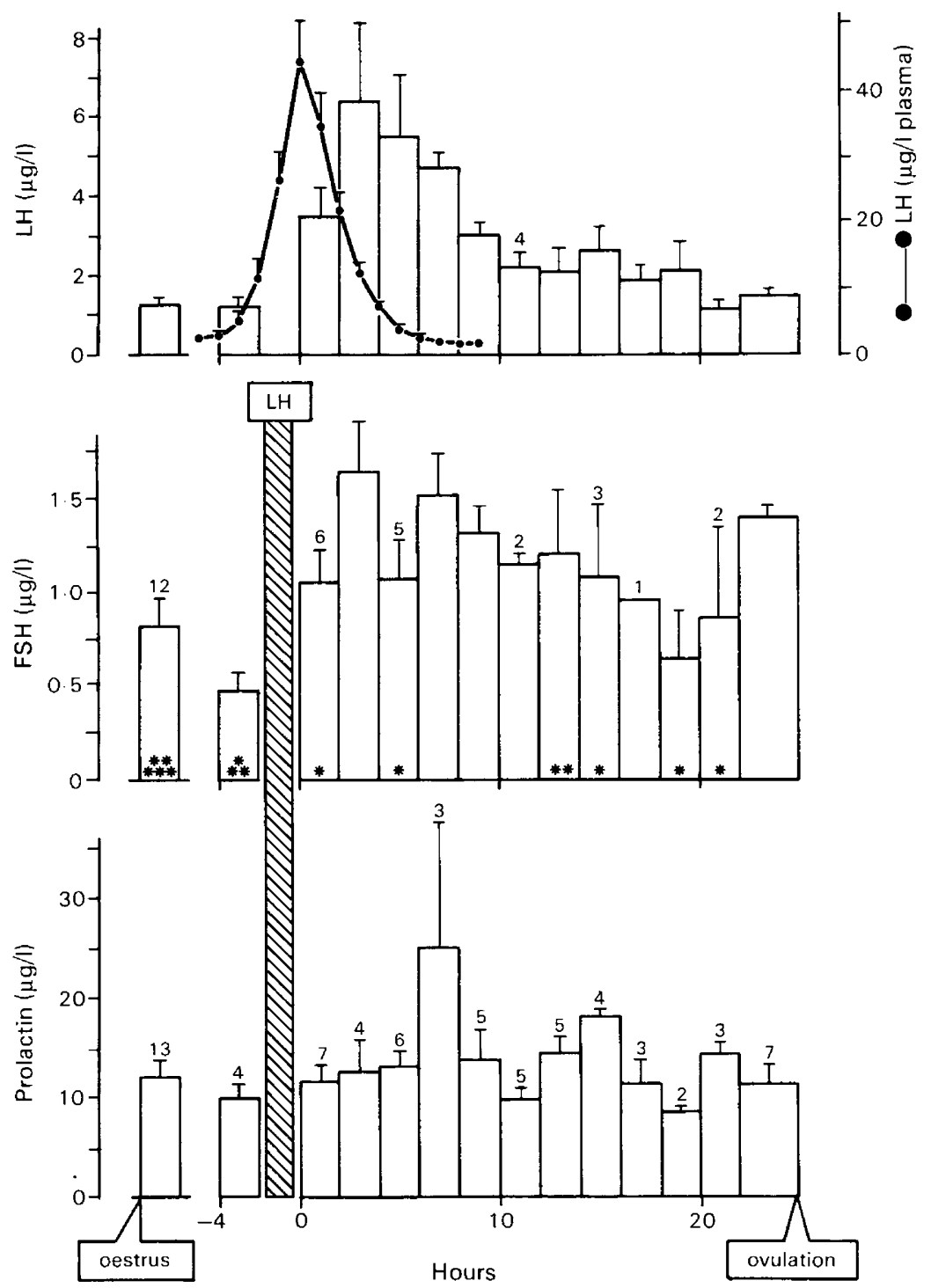

Text-fig. 2. Pituitary hormone concentrations in the fluid of preovulatory bovine follicles from the onset of oestrus until ovulation measured in 2 -h periods relative to the maximum $\mathrm{LH}$ concentration in the peripheral blood $(-, n=10)$. Values are mean \pm s.e.m. for the numbers of follicles shown in (c) and when different in (a) and (b). The follicles with an FSH concentration below the detection limit are indicated by asterisk $\left({ }^{*}\right)$. 
concentrations $(\mu \mathrm{g} / \mathrm{l})$ of $\mathrm{LH}, \mathrm{FSH}$ and prolactin in the follicular fluid were $1.26 \pm 0.18(n=13)$, $0.83 \pm 0.14(n=12)$ and $12.16 \pm 1.68(n=13)$ in terms of NIH-LH-B9, bFSH and NIH-P-B3 respectively. Four follicles were collected between 4 and $2 \mathrm{~h}$ before the LH plasma peak, and 54 follicles were collected over 2-h periods after the LH plasma peak. Text-figure 2 presents the mean concentrations of the pituitary hormones at each period and the LH concentration in the peripheral blood. The pattern of the LH concentration in the follicular fluid showed a maximum at about $4 \mathrm{~h}$ after the maximum recorded in the peripheral blood. The LH concentration in follicular fluid at 2-4 $\mathrm{h}$ and $4-6 \mathrm{~h}$ after the LH peak was significantly higher $(P<0.005$ for both periods) than that of follicles collected before the LH plasma peak; the concentration between 2 and $6 \mathrm{~h}$ was also significantly higher $(P<0.05$ for all $)$ than that at $10-20 \mathrm{~h}$ and $22-25 \mathrm{~h}$. From about 7 to $20 \mathrm{~h}$ the LH concentration in the follicular fluid was higher $(P<0.02)$ than that in peripheral blood. By $20-25 \mathrm{~h}$ the LH concentration in follicular fluid was similar to that measured in follicles collected before the LH plasma peak. The FSH concentration (Text-fig. 2) in the period before the LH plasma peak was significantly lower $(P<0.025)$ than that during the period from 0 to $18 \mathrm{~h}$. The apparently lower concentration at $18-20 \mathrm{~h}$ was not different from those in the preceding or succeeding periods. Just before ovulation the FSH concentration was significantly higher $(P=0.05)$ than before the LH plasma peak. The prolactin concentration in the follicular fluid (Text-fig. 2) fluctuated throughout the period of preovulatory follicular development from the onset of oestrus until ovulation. The apparently elevated concentrations at 6-8 h, 14-16 h and 20-22 $\mathrm{h}$ after the LH plasma peak were not significantly different from the concentrations during other periods.

Steroid and pituitary hormone concentrations in the fluid of antral non-atretic follicles during the luteal phase of the oestrous cycle

The mean concentrations of dehydroepiandrosterone, androstenedione and oestrone in the fluid of the 9 follicles of $15-19 \mathrm{~mm}$ collected during the luteal phase of the oestrous cycle were 0.006 $\pm 0.002,0.015 \pm 0.007$ and $0.033 \pm 0.007 \mu \mathrm{mol} / 1$ respectively. These concentrations were significantly lower $(P<0.001$ for all $)$ than for preovulatory follicles collected before the LH surge. The mean concentrations of $\mathrm{LH}$ and prolactin were $0.87 \pm 0.11$ and $10.80 \pm 2.25 \mu \mathrm{g} / \mathrm{l}$ respectively, which were not significantly different from the values for preovulatory follicles. All the FSH values were below the detection limit of the assay $(P<0.01$ compared with values for preovulatory follicles).

\section{Discussion}

After the onset of oestrus and before the LH surge the follicular fluid concentrations of the steroids were at least 14-fold higher than those in follicles collected during the luteal phase of the oestrous cycle. This indicates that preovulatory follicles are more steroidogenically active than large nonatretic luteal-phase follicles. Before the LH surge the follicular fluid concentration of androstenedione exceeded that of other steroids, but was lower than that reported for oestradiol (Dieleman et al., 1983). At $72 \mathrm{~h}$ after prostaglandin treatment, the concentration of androstenedione in preovulatory follicles (Ireland \& Roche, 1982) was about one-half of the values reported here, but in large non-ovulatory follicles during the luteal phase of the oestrous cycle (Ireland \& Roche, 1983) the androstenedione value was higher than that found in the present study for similar follicles. Considerably lower androstenedione concentrations were given by Henderson et al. (1982) for follicles larger than $10 \mathrm{~mm}$, which were not dated as to the stage of the oestrous cycle. The finding that the follicular fluid concentration of oestrone before the LH surge was much lower than that of oestradiol confirms earlier observations (Lunaas, 1964). Comparison of the steroid concentrations in preovulatory bovine follicles before the LH surge with those reported for women (McNatty et al., 1976), sows (Ainsworth, Tsang, Downey, Marcus \& Armstrong, 1980) and ewes 
(Scaramuzzi, Baird, Clarke, Martensz \& Van Look, 1980) shows that the proportions of the steroids involved in oestrogen synthesis are most similar in cows and women.

After the onset of oestrus and before the LH surge in the peripheral blood the follicular fluid concentration of FSH was higher than that in large non-atretic luteal-phase follicles. This corresponds with the reported higher oestradiol concentration in preovulatory follicles (Dieleman et al., 1983), since FSH is supposed to stimulate aromatizing activity (Hillier, 1981), and with the observation that large non-atretic follicles during the luteal phase were non-ovulatory (Ireland \& Roche, 1983; S. J. Dieleman, unpublished data). The follicular fluid concentrations of LH, FSH and prolactin before the LH surge were similar to those reported by Henderson et al. (1982) for follicles larger than $10 \mathrm{~mm}$, when the FSH concentration reported here is expressed in the same terms as used by these authors $(0.83 \mu \mathrm{g} \mathrm{bFSH} / 1$ : converted value $83 \mu \mathrm{g}$ NIH-FSH-B $1 / 1$; Cheng, 1978). In the fluid of human preovulatory follicles the concentrations of LH and FSH were higher and of prolactin lower than those of luteal-phase follicles (McNatty, Hunter, McNeilly \& Sawers, 1975); similar observations were made for LH and prolactin in the ewe (McNatty et al., 1981b).

In-vitro experiments by Fortune \& Hansel (1979) demonstrated that thecal cells are the primary source of androgens, while granulosa cells produce oestrogens. In the preovulatory follicles under study, the concentrations of the steroids intermediary in the oestrogen synthetic pathway decreased rapidly during the period from 0 to $6 \mathrm{~h}$ after the LH plasma peak, whereas no significant decrease of the oestradiol concentration had been observed during this phase (Dieleman et al., 1983). The patterns of the androstenedione and dehydroepiandrosterone concentrations showed that $\Delta^{5}-3 \beta$ hydroxysteroid dehydrogenase activity probably is continuous throughout preovulatory growth as shown in the theca interna in sheep (Hay \& Moor, 1975). This implies that the observed immediate decrease of the androstenedione concentration may be due to inhibition at an earlier step in the $\Delta^{5}$. pathway. The continuous increase of the ratio of oestrone to androstenedione from $0 \mathrm{~h}$ until the sharp decrease at $14 \mathrm{~h}$ indicates that inhibition of aromatase became evident at about $14 \mathrm{~h}$ after the LH plasma peak, probably causing the increase of the androstenedione concentration. The pattern of the ratio of oestradiol to oestrone suggests that $17 \beta$-hydroxysteroid dehydrogenase (17 $\beta$-HSD) activity remained present until shortly before ovulation.

The successive decrease of the follicular fluid concentrations of androstenedione, oestrone and oestradiol after the LH plasma peak, and the finding that the androstenedione concentration before the LH surge was about 8-fold higher than that of testosterone, indicate that androstenedione is the major aromatase substrate. Furthermore, the fall of the oestrone concentration occurred after the decrease of testosterone, which came about at a slower rate than that of androstenedione as shown by the ratio of these two steroids. Henderson \& Moon (1979) assumed a preference for testosterone as aromatase substrate based on differences in the rate of conversion of administered testosterone and androstenedione by granulosa cells from randomly collected large follicles during luteinization in culture. However, this difference may be due to low 17\%-HSD activity. Therefore, it is supposed that synthesis of oestradiol in preovulatory bovine follicles in vivo takes place through the pathway: pregnenolone $\rightarrow$ 17 $\alpha$-hydroxypregnenolone $\rightarrow$ dehydroepiandrosterone $\rightarrow$ androstenedione $\rightarrow$ oestrone $\rightarrow$ oestradiol.

The LH concentration in the fluid of preovulatory bovine follicles started to rise when the $\mathrm{LH}$ concentration in the peripheral blood had already reached its maximum, as was reported by McNatty, Dobson, Gibb, Kieboom \& Thurley (1981a) for ovine follicles after administration of LH-releasing hormone to ewes under anaesthesia at 10 days after oestrus. The effects of $\mathbf{L H}$, however, were already evident concurrently with the LH plasma rise, as shown by the rapid decrease of the androstenedione concentration in the follicular fluid. This lag may be due to occupation of free $\mathrm{LH}$ receptors since the inward flow of small proteins like gonadotrophins may not be impeded by the blood-follicle barrier (Cran, Moor \& Hay, 1976). The maximum LH concentration in follicular fluid was about one seventh of that in the peripheral blood but it remained elevated for a longer period than that in the peripheral blood, as reported in experiments with ewes (McNatty et al., 1981a). The observed tailing of the LH peak in the follicular fluid may be 
due to a slower efflux than influx of $\mathrm{LH}$, as indicated by the reported accumulation of small proteins in follicular fluid (Andersen, Krøll, Byskov \& Faber, 1976). Sakai \& Channing (1979) suggested that the increase of the $\mathrm{LH}$ concentration in the fluid of preovulatory monkey follicles could reflect accumulation of LH subunits rather than biologically active LH. Since, however, the follicular fluid concentrations of $\mathrm{LH}$ did not return to the level before the $\mathrm{LH}$ plasma peak until after $20 \mathrm{~h}$ when morphological and functional luteinization of the membrana granulosa became apparent (Dieleman et al., 1983), it is suggested that the tailing of the LH peak in the follicular fluid may be due to a gradual release of $\mathrm{LH}$ from the receptors in the follicular wall.

Ireland \& Roche (1982) reported an FSH peak coinciding with the preovulatory plasma LH peak. Compared with this reported FSH surge, the FSH concentration in the fluid of preovulatory follicles started to rise after the onset of the increase in the peripheral blood. From about $6 \mathrm{~h}$ after the LH plasma peak the pattern of the FSH concentration in the follicular fluid showed a gradual decrease until $20 \mathrm{~h}$. This again may be explained as the result of a cumulative effect of slow efflux and gradual release of FSH from the receptors in the follicular wall. From $20 \mathrm{~h}$ until ovulation the FSH concentration increased and was significantly higher than in follicles collected before the LH/ FSH peak. In peripheral blood of sheep a second FSH peak was reached shortly before ovulation (Baird, Swanston \& McNeilly, 1981). The high follicular fluid concentration of FSH at the time of ovulation is possibly correlated with the supposed stimulatory role of FSH for ovulatory processes like mucification of the cumulus cells and activation of plasmin (see Fritz \& Speroff, 1982, for review). The prolactin concentration in the follicular fluid fluctuated throughout preovulatory development, and its overall mean concentration $(12.97 \pm 6.50 \mu \mathrm{g} / 1, n=71)$ was similar to that observed in peripheral blood samples taken each hour during preovulatory development (S. J. Dieleman, unpublished data). It is supposed that the measured prolactin concentration in the follicular fluid reflected the in-vivo concentrations, since a detailed study of the changes occurring at the time of ovariectomy demonstrated that increase of the prolactin concentration in the peripheral blood due to the stress of surgery started after the ovarian blood vessels were clamped (S. J. Dieleman, unpublished observations).

The results of this study indicate that androstenedione is the major substrate for aromatase and oestradiol biosynthesis is terminated by direct inhibition of androgen production preceding eventual inhibition of aromatizing activity. It is supposed that in vivo LH is the major regulatory gonadotrophin for steroidogenesis and with FSH is required throughout preovulatory development until luteinization and oocyte maturation (Kruip, Cran, Van Beneden \& Dieleman, 1983) are completed.

Bovine pituitary hormones were kindly supplied by the pituitary hormone distribution program of the NIAMDD, Bethesda, U.S.A. We thank Professor A. H. Willemse and Professor P. A. Voogt for reading the manuscript; Dr P. Fontijne and Dr G. C. van der Weyden and assistants for the surgery; Mrs D. M. Blankenstein, Mrs W. H. R. de Jong, Mr A. V. P. van de Poll and Mr H. S. Wouterse for technical assistance; Mr S. H. J. Mook and co-workers for tending the animals; and Mr W. Bes for drawing the figures.

\section{References}

Ainsworth, L., Tsang, B.K., Downey, B.R., Marcus, G.J. \& Armstrong, D.T. (1980) Interrelationships between follicular fluid steroid levels, gonadotropic stimuli, and oocyte maturation during preovulatory development of porcine follicles. Biol. Reprod. 23, 621-627.

Andersen, M.M., Krøll, J., Byskov, A.G. \& Faber, M. (1976) Protein composition in the fluid of individual bovine follicles. $J$. Reprod. Fert. 48, 109-118.

Baird, D.T., Swanston, I.A. \& McNeilly, A.S. (1981)
Relationship between LH, FSH and prolactin concentration and the secretion of androgens and estrogens by the preovulatory follicle in the ewe. Biol. Reprod. 24, 1013-1025.

Beckers, J.F., Closset, J., Maghuin-Rogister, G. \& Hennen, G. (1977) Bovine follitropin, isolation and characterization of the native hormone and its $\alpha$ and $\beta$ subunits. Biochimie 59, 825-831.

Bevers, M.M., Willemse, A.H. \& Kruip, Th.A.M. (1978) 
Plasma prolactin levels in the sow during lactation and the postweaning period as measured by radioimmunoassay. Biol. Reprod. 19, 628-634.

Cheng, K.W. (1978) Development and characterization of a homologous radioimmunoassay for bovine follicle stimulating hormone. J. Endocr. 77, 185-193.

Closset, J., Vandalem, J.L. \& Hennen, G. (1975) Human luteinizing hormone. Isolation and characterization of the native hormone and its $\alpha$ and $\beta$ subunits. Eur. $J$. Biochem. 57, 325-333.

Cran, D.G., Moor, R.M. \& Hay, M.F. (1976) Permeability of ovarian follicles to electrodense macromolecules. Acta endocr., Copenh. 82, 631-636.

Dieleman, S.J. \& Schoenmakers, H.J.N. (1979) Radioimmunoassays to determine the presence of progesterone and estrone in the starfish Asterias rubens. Gen. comp. Endocr. 39, 534-542.

Dieleman, S.J., Kruip, Th.A.M., Fontijne, P., de Jong, W.H.R. \& van der Weyden, G.C. (1983) Changes in oestradiol, progesterone and testosterone concentrations in follicular fluid and in the micromorphology of preovulatory bovine follicles relative to the peak of luteinizing hormone. J. Endocr. 97, 31-42.

Fortune, J.E. \& Hansel, W. (1979) Effect of LH surge on steroid secretion by theca and granulosa cells of bovine preovulatory follicles. Biol. Reprod. 20, suppl. 1, 46, Abstr.

Fritz, M.A. \& Speroff, L. (1982) The endocrinology of the menstrual cycle: the interaction of folliculogenesis and neuroendocrine mechanisms. Fert. Steril. 38, 509-529.

Hay, M.F. \& Moor, R.M. (1975) Distribuiton of $\Delta^{5}-3 \beta$ hydroxysteroid dehydrogenase activity in the Graafian follicle of sheep. J. Reprod. Fert. 43, 313-322.

Henderson, K.M. \& Moon, Y.S. (1979) Luteinization of bovine granulosa cells and corpus luteum formation associated with loss of androgen-aromatizing ability. J. Reprod. Fert. 56, 89-97.

Henderson, K.M., McNeilly, A.S. \& Swanston, I.A. (1982) Gonadotrophin and steroid concentrations in bovine follicular fluid and their relationship to follicle size. $J$. Reprod. Fert. 65, 467-473.

Hillier, S.G. (1981) Regulation of follicular oestrogen biosynthesis: a survey of current concepts. $J$. Endocr. 89, 3P-18P.

Ireland, J.J. \& Roche, J.F. (1982) Development of antral follicles in cattle after prostaglandin-induced luteolysis: changes in serum hormones, steroids in follicular fluid, and gonadotropin receptors. Endocrinology 111, 2077-2086.

Ireland, J.J. \& Roche, J.F. (1983) Development of nonovulatory antral follicles in heifers: changes in steroids in follicular fluid and receptors for gonadotropins. Endocrinology 112, 150-156.

Kruip, Th.A.M. \& Dieleman, S.J. (1982) Macroscopic classification of bovine follicles and its validation by micromorphological and steroid biochemical procedures. Reprod. Nutr. Dévelop. 22, 465-473.

Kruip, Th.A.M., Cran, D.G., Van Beneden, Th.H. \& Dieleman, S.J. (1983) Structural changes in bovine oocytes during final maturation in vivo. Gamete Res. 8, In Press.

Lunaas, T. (1964) Distribution of oestrone and oestradiol in the bovine ovary. Acta vet. scand. 5, 35-49.

MeNatty, K.P., Hunter, W.M., McNeilly, A.S. \& Sawers, R.S. (1975) Changes in the concentration of pituitary and steroid hormones in the follicular fluid of human Graafian follicles throughout the menstrual cycle. $J$. Endocr. 64, 555-571.

McNatty, K.P., Baird, D.T., Bolton, A., Chambers, P., Corker, C.S. \& McLean, H. (1976) Concentration of oestrogens and androgens in human ovarian venous plasma and follicular fluid throughout the menstrual cycle. J. Endocr. 71, 77-85.

McNatty, K.P., Dobson, C., Gibb, M., Kieboom, L. \& Thurley, D.C. (1981a) Accumulation of luteinizing hormone, oestradiol and androstenedione by sheep ovarian follicles in vivo. $J$. Endocr. 91, 99-109.

McNatty, K.P., Gibb, M., Dobson, C., Thurley, D.C. \& Findlay, J.K. (1981b) Changes in the concentration of gonadotrophic and steroidal hormones in the antral fluid of ovarian follicles throughout the oestrous cycle of the sheep. Aust. J. biol. Sci. 34, 67-80.

Peters, H. \& McNatty, K.P. (1980) Follicular fluid, ovarian hormones. In The Ovary, pp. 36-60. Granada Publishing Ltd, London.

Sakai, C.N. \& Channing, C.P. (1979) Uptake of luteinizing hormone by the preovulatory monkey follicle in vivo. Endocrinology 104, 1226-1233.

Scaramuzzi, R.J., Baird, D.T., Clarke, I.J., Martensz, N.D. \& Van Look, P.F.A. (1980) Ovarian morphology and the concentration of steroids during the oestrous cycle of sheep actively immunized against androstenedione. J. Reprod. Fert. 58, 27-35.

Scheffé, H. (1959) The Analysis of Variance. John Wiley, New York.

Suzuki, K. \& Tamaoki, B. (1980) Postovulatory decrease in estrogen production is caused by the diminished supply of aromatizable androgens to ovarian aromatase. Endocrinology 107, 2115-2116.

Van Landeghem, A.A.J., Poortman, J., Deshpande, N., Di Martino, L., Tarquini, A., Thijssen, J.H.H. \& Schwarz, F. (1981) Plasma concentration gradient of steroid hormones across human mammary tumours in vivo. J. Steroid Biochem. 14, 741--747.

Wang, C. \& Chan, V. (1982) Divergent effects of prolactin on estrogen and progesterone production by granulosa cells of rat Graafian follicles. Endocrinology 110, 1085-1093.

Received 16 March 1983 